\title{
An Overview of Forest Cover and Management in Italy
}

\author{
Nicolò Di Marzio
}

\begin{abstract}
Nacrtak
Over the centuries, alongside multiple changes in socio-economical conditions, needs and technical possibilities, Italian forest and forest management have gone through a dynamic and complex evolution process. In the last decade, forest lands in Italy have been constantly growing and nowadays cover almost 11 million hectars, accounting for $36.4 \%$ of the total national territory. Several quantitative and qualitative aspects of forest resources, regarding species composition, actual and available stock, ownership, volume of utilization, accessibility, terrain features and others, have been described through the analysis of the National Forest Inventory (INFC2005). The most represented forest typology is "coppice with standards", while many forests are in a mature stage, waiting for conversion to transitional stands. Concerning forest logging, full length harvesting and winching-skidding extraction are the most widespread systems, but in many areas the low-openness conditions represent a limiting factor for logging distances, expecially in high slope classes, where sustainable and cost-effective operations are primary. The modern solutions allowed by technological progress, in addition to the growing environmental awareness and need of a sustainable management at multiple level, require an efficient forest communication management and professional training of operators, in a challenging scenario that Italy is called to approach.
\end{abstract}

Keywords: Italian forest resources, National Inventory, forest management, accessibility, sustainable management

\section{Introduction - Uvod}

The contemporary forest pattern in Italy is the result of a complex assemblage of different land covers and geo-morphological situations, as a result of a progressive natural and man-made modification process, following cultural, socio-economic and environmental changes through millennial history in the whole territory. An example of strong influence on the composition of forest since medieval times and until the IX century has been represented by naval construction, for civil and military purposes, until the switch to iron-hulled ships (Agnoletti 2018). Along with population growth, other major influences have been given by the relationship with agricultural practices, the creation of hunting forests, where the structure was shaped in order to create suitable conditions for particular animal species, by different grazing management techniques for forest pastures and grasslands on hillside and mountain areas, and by the production of fuelwood and charcoal from every kind of forest, according to the needs and local traditions (Agnoletti 2018). By the National Unity (1861), Italian forest has undergone big modifications and impacts connected to the expansion of big towns and agricultural lands, the strong need of raw material for railway sleepers to support the creation of new rail networks, and the first national forest law of 1877, which allowed the beginning of reforestation, although with many hardships, operated by new consortia and forest administration (Gabbrielli 2007). Such process was disrupted by the First World War events, because of the considerable wood demand for military logistic and the need to provide a valid alternative to fossil fuel and timber, which was no longer possible to import from Austria (Ermacora 2009). By the interwar the negative trend of forest cover was reversed (Agnoletti 2018), whilst it was affected when the Second World War brought a new arms race and self-man- 
agement of manufacture, resulting once again in a growing demand for raw material and charcoal, especially for foundries. The management of forest in this tough time was therefore oriented to productive purposes in several areas, so the positive trend of forest cover started to be more consistent in the second half of the century, thanks to legislative measures adopted and deep socio-economical changes such as land abandonment as well as the arrival of petroleum products and reinforced concrete as new energetic and building resources, and it still continues to be positive to date.

The aim of this paper is to give an overview of the actual situation in Italy concerning forest cover, forest management, main logging and extraction methods, with a few final remarks about future prospects for forest management, in view of the current needs.

\section{Material and methods Materijal i metode}

All data presented in this paper have been gathered from the National forest inventory, official documents and databases, as well as from the National Report on the status of forest resources and other cited articles available on Google Scholar. Microsoft Excel has been used to implement data in order to make tables and graphs. This paper provides information about the current status of forest resources, stressing some main aspects of forest management and utilization in order to better focus on future perspectives.

\section{Forest resources and national forest inventory - Šumski resursi i nacionalna inventura šuma}

The first Italian Forest Inventory (NFI) was carried out in 1985. According to the definition of forest adopted at that time, the national forest cover was about $8,675,000$ ha with $80 \%$ of broadleaves, $16 \%$ of coniferous and $4 \%$ of clear mixed situations (www. infc.it).

The second Forest and Carbon Pools Inventory was carried out in 2005, following the International FAO definition of forest and CORINE Land Cover classes at a general level. The third National Inventory (INFC2015) has been completed partially at present; therefore, it is only possible to make a comparison with the previous situation on the basis of data projection. For future considerations of this paper, the second one (INFC2005) will be considered.
Fig. 1 shows the amount of forest cover in the above-mentioned inventories. The figure only gives a general idea about the trend of forest cover (forests + other wooded lands) through the years, accounting for an increase from $27.8 \%$ of total forest land in 1985 to $36.4 \%$ in 2015. In this figure, timber/wood plantations have not been considered, as data were not provided in preliminary results of INFC2015.

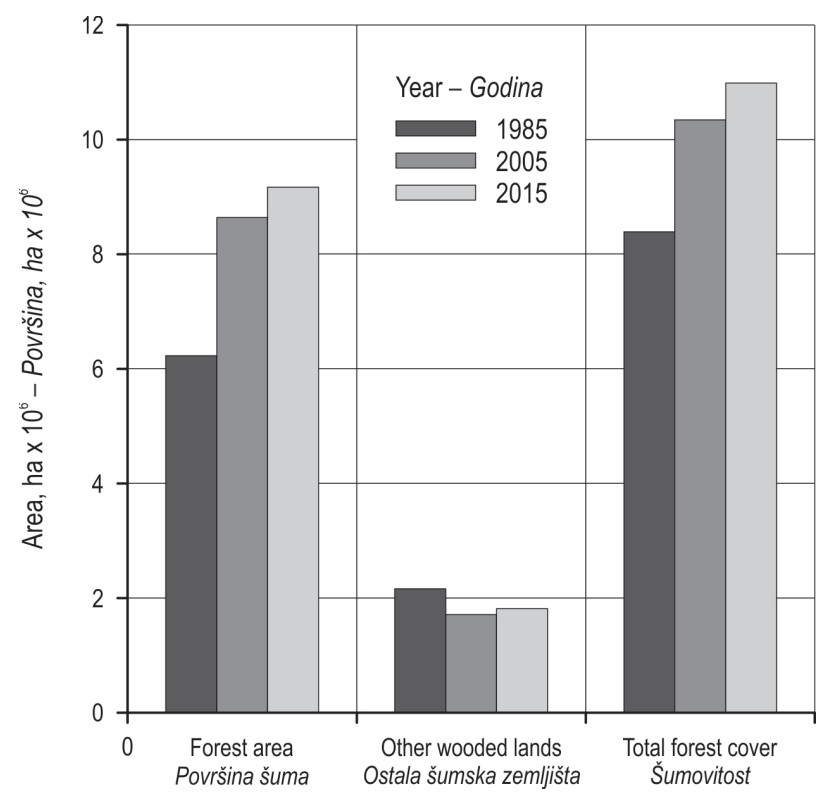

Fig. 1 Forest cover throughout national inventories

Slika 1. Šumovitost prema nacionalnim inventurama

According to the European standard and within FAO definition, forest category at the second level of classification is composed of tall tree forests $(98 \%)$, productive timber/wood plantations $(0.4 \%)$ and temporarily unstock areas $(0.2 \%)$, whether natural or artificial. Other forested areas, which do not completely meet the requirements of FAO definition of forest, are classified as other wooded lands. On balance, the completely forested national territory (forest + other wooded lands) accounts for $34.7 \%$ in INFC2005, with the assumption to be $2 \%$ more in INCF2015.

Tall tree forests are classified on the basis of 17 forest categories, according to the prevalent species in terms of crown cover, and three forest categories are considered for timber/wood plantations (Gasparini et al. 2016)

Table 1 shows the area, wood stock and annual increment of each forest category of INFC2005. The most forested regions are Liguria and Trentino (north part of the country), where forest cover is about 62.6 $\%$ and $60.5 \%$, respectively, of regional area. 
Table 1 Area, volume and annual increment of forest categories (INFC2005)

Tablica 1. Površina, drvna zaliha i godišnji prirast visokih šuma (INFC2005)

\begin{tabular}{|c|c|c|c|}
\hline Tall tree forest categories - Kategorija visokih šuma & Area - Površina, ha & $\begin{array}{l}\text { Volume - Drvna zaliha, } \\
\text { m³ }^{3}\end{array}$ & $\begin{array}{l}\text { Annual increment - } \\
\text { Godišnji prirast, } \mathrm{m}^{3}\end{array}$ \\
\hline Other coniferous forests - Ostale sastojine četinjača & 63.407 & 12.496 .202 & 404.893 \\
\hline Abies alba Mill. & 68.460 & 29.244 .196 & 565.119 \\
\hline Other evergreen broadleaved forests - Ostale zimzelene sastojine listača & 84.712 & 4.476 .479 & 226.448 \\
\hline Pinus sylvestris L. and Pinus uncinata Mill. & 151.671 & 29.011 .580 & 529.251 \\
\hline Quercus suber L. & 168.602 & 8.444 .671 & 220.298 \\
\hline Mediterranean pines - Sastojine mediteranskih borova & 226.101 & 30.204 .769 & 833.255 \\
\hline Hygrophilous forests - Poplavne šume & 229.054 & 24.382 .385 & 960.264 \\
\hline Black pines group - Borove šume & 236.467 & 53.280 .460 & 1.404 .011 \\
\hline Larix decidua Mill. and Pinus cembra L. & 382.372 & 76.930 .988 & 1.282 .925 \\
\hline Picea abies L. & 586.082 & 218.166 .422 & 4.567 .710 \\
\hline Quercus ilex L. & 620.318 & 45.598 .302 & 1.453 .949 \\
\hline Castanea sativa Mill. & 788.408 & 139.697 .903 & 4.941 .237 \\
\hline Ostrya carpinifolia Scop. and Carpinus betulus L. & 852.202 & 68.949 .448 & 2.452 .274 \\
\hline Other deciduous broadleaved forests - Ostale listopadne sastojine & 994.777 & 94.003 .164 & 4.006 .403 \\
\hline Mediterranean oak spp. - Sastojine mediteranskih hrastova & 1.010 .986 & 103.797 .336 & 3.233 .075 \\
\hline Fagus sylvatica L. & 1.035 .103 & 240.009 .507 & 5.597 .810 \\
\hline Temperate oak spp. - Sastojine kontinentalnih hrastova & 1.084 .247 & 77.405 .681 & 2.206 .439 \\
\hline Total tall tree forests - Ukupna površina visokih šuma & 8.582 .969 & 1.256 .099 .493 & 34.885 .361 \\
\hline \multicolumn{4}{|c|}{ Timber/wood plantation categories - Kategorije plantaža } \\
\hline Poplar plantations - Plantaže topole & 66.269 & 7.518 .275 & 621.688 \\
\hline Other broadleaved plantations - Plantaže ostalih listača & 40.985 & 1.976 .387 & 196.488 \\
\hline Coniferous plantations - Plantaže četinjača & 14.998 & 2.751 .832 & 121.672 \\
\hline Total timber/wood plantations - Plantaže, ukupno & 122.252 & 12.246 .494 & 939.848 \\
\hline Temporarily unstocked areas - Privremeno neproizvodne površine & 53.981 & 1.070 .512 & 47.083 \\
\hline Total - Ukupno & 8.759 .202 & 1.269 .416 .499 & 35.872 .292 \\
\hline
\end{tabular}

Fig. 2 shows the proportions of the first 17 categories. Temperate and Mediterranean oak, beech, chestnut, hornbeam, holm oak and spruce are the most representative species in Italy. Because of the great variety of landscapes, resulting from socio-political changes and connected with the physical fea-

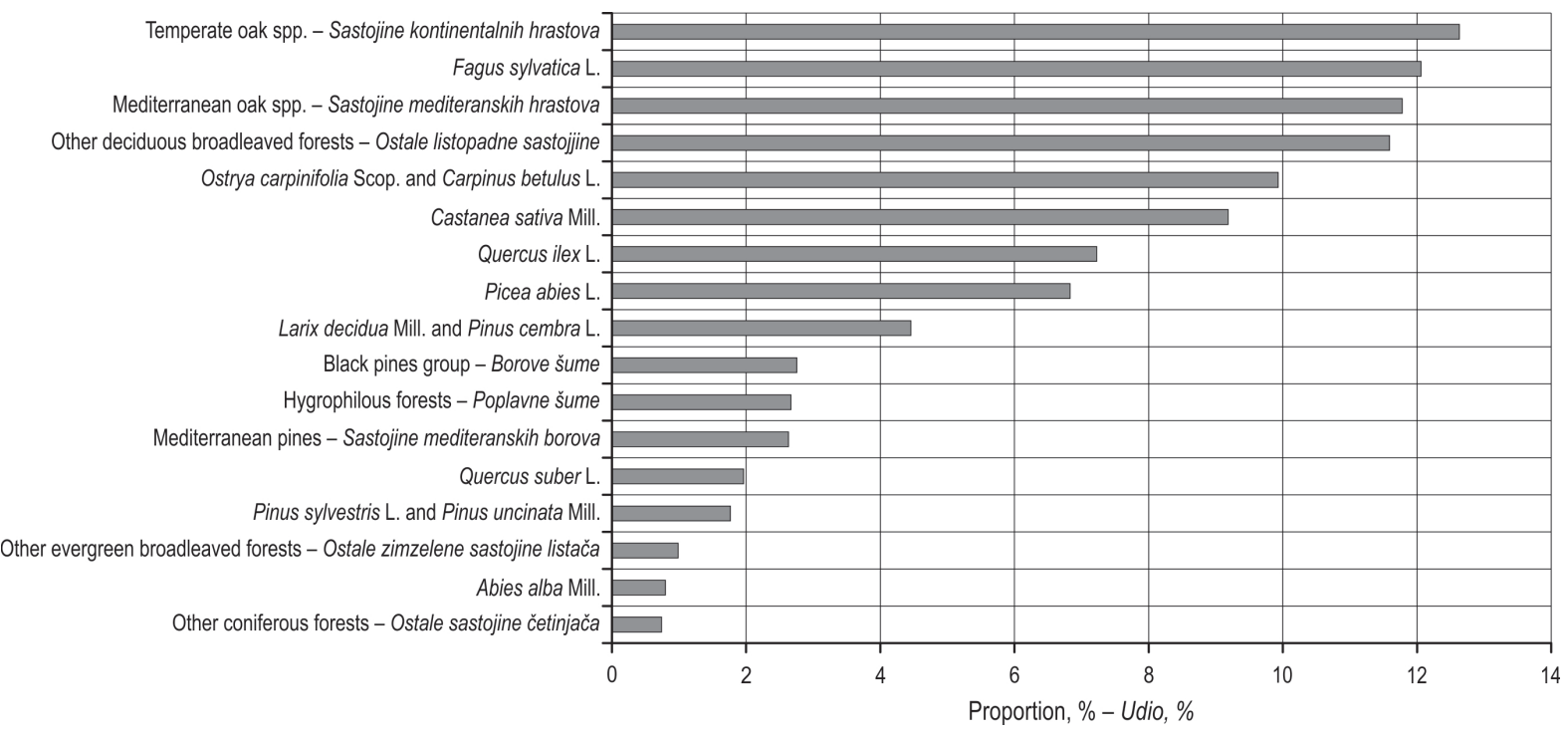

Fig. 2 Proportion of tall tree forest categories

Slika 2. Udio kategorija visokih šuma 
tures and gradients of the environment (climate, lithology, morphology), forests are highly diversified at national scale, ranging from alpine forests comparable to central-north European situations, to Mediterranean and arid climates forests, more similar to North African typologies (Cesaro et al. 2009).

Tall tree forests are mainly composed of broadleaves, which are dominant in almost the all regions, with few exceptions in Alpine areas. Fig. 3 shows the distribution of pure and mixed forests. A similar situation can be found in timber/wood production, composed of $84 \%$ of pure broadleaves.

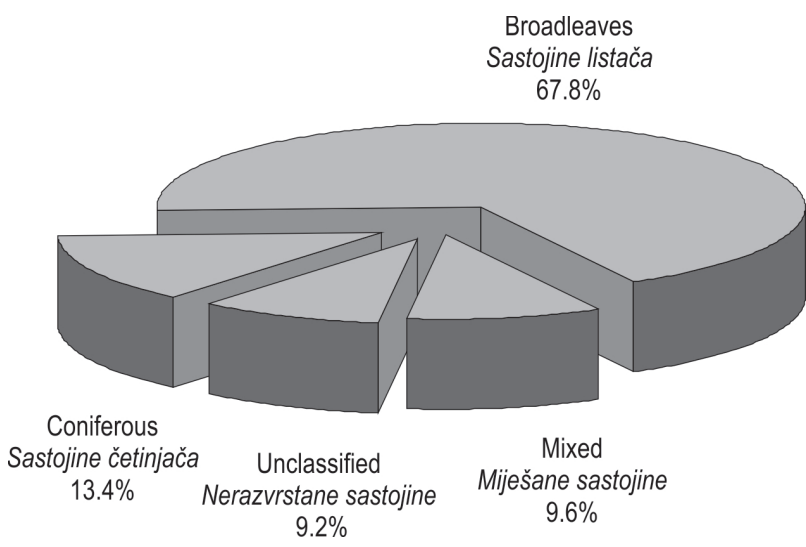

Fig. 3 Distribution of broadleaved and coniferous stands

Slika 3. Udio sastojina listača i četinjača

Concerning the ownership, the majority of forests are private $(66.2 \%$ of forest category and $49.7 \%$ of other wooded lands), mostly owned by individual owners, while public ownership is more represented within provincial and municipal administrations, as shown in Fig.4

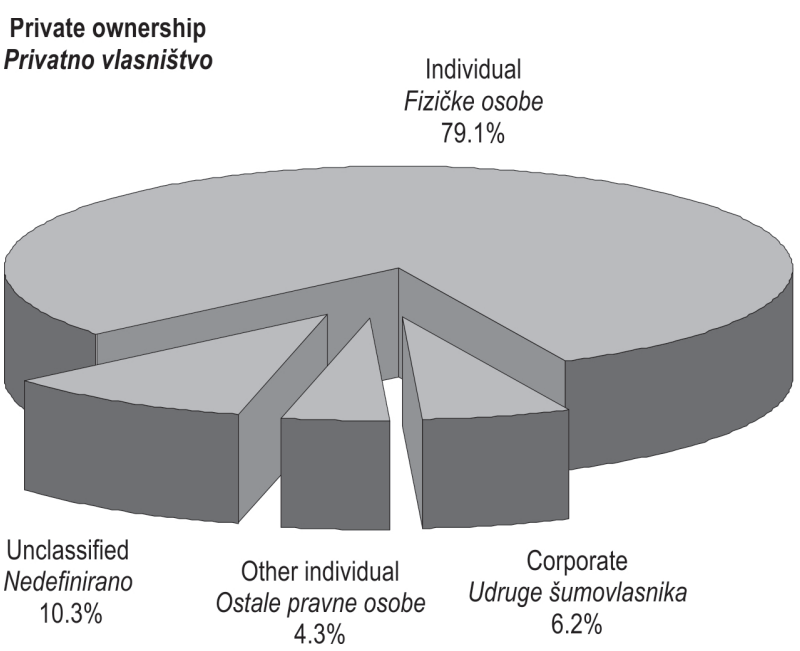

Fig. 4 Forest ownership distribution

Slika 4. Udio i raspodjela šumovlasništva
The predominance of private ownership is also typical of many surrounding Countries, i.e., accounting for more than $75 \%$ of the total forest area in Austria, France and Slovenia (Hirsch et al. 2007), while the balance is reversed in Switzerland and Croatia, accounting for over $68 \%$ and $78 \%$, respectively, of public ownership.

The majority of forests in Italy are coppices (41.8 $\%$ of total forests), mostly represented by »coppice with standards" typology, where the utilization in a felling generally consists of about $80-85 \%$ of the above-ground woody biomass (Venanzi et al. 2016) and, according to the regional law, the release of scattered standards between 20 and 120 per hectare, within one or two age classes. As a consequence of the massive abandonment of coppice management from the 1950s, due to changes in the economy and society such as the creation of major population centers and the drop in demand for fuelwood following fossil fuels entry, about $89 \%$ of the coppices nowadays are in a mature status of »aged coppice«. According to Ciancio et al. (2002), coppice conversions to transitional stands and, subsequently, to high forests are expected to further increase.

High forests represent $36.1 \%$ of total Italian woodlands. Within the category of tall tree forest (see Table 1), they include $15.8 \%$ of even-aged and $13.5 \%$ of uneven-aged stands. Most of the evenaged high forests are in the age classes 41 to 80 (Gasparini 2019).

The most represented typology of a logging company is the individual or family enterprise (Baldini et al. 2006), which sometimes relies on external seasonal workers or outsourcing to get some work

\section{Public ownership}

Javno vlasništvo

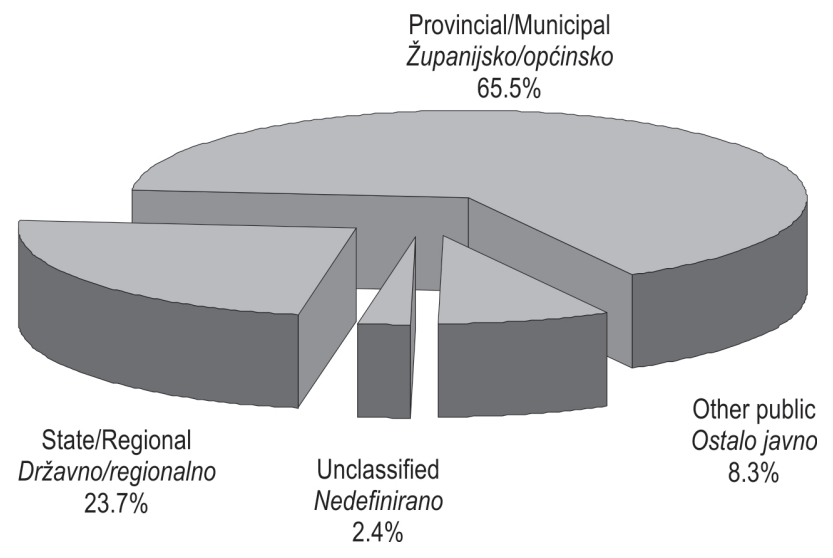


done. In some other cases, companies work both in forestry and agricultural industry, to round up the machines maintenance costs.

\section{Forest logging and accessibility Pridobivanje drva i otvorenost šuma}

According to INFC 2005, 88.4\% of forest category results available to be harvested, which corresponds to an available volume of about 31.7 million of $\mathrm{m}^{3}$ (according to the average annual increment of 4.1 $\mathrm{m}^{3} \mathrm{ha}^{-1}$ ). Unavailable areas, in line with FAO definition (2000), are considered on the basis of high legislative restrictions or policy decisions (including areas where forest harvesting is limited by nature conservation or other scientific, historical, cultural restrictions) as well as low productivity issues (for example access constraints and physical impediments affecting skidding distances and stumpage value).

The total volume of forest logging estimated in INFC2005 was about 13.8 million of $\mathrm{m}^{3}$. According to the Italian Institute for Statistics (ISTAT) a general decrease of forest utilization has been observed within the $1999-2015$ period, thereby confirming Italy as one of the countries with the lowest utilization rate, in comparison with the central-southern European standard, and strongly dependent on foreign imports for both fuelwood and raw timber (Mariano et al. 2019).

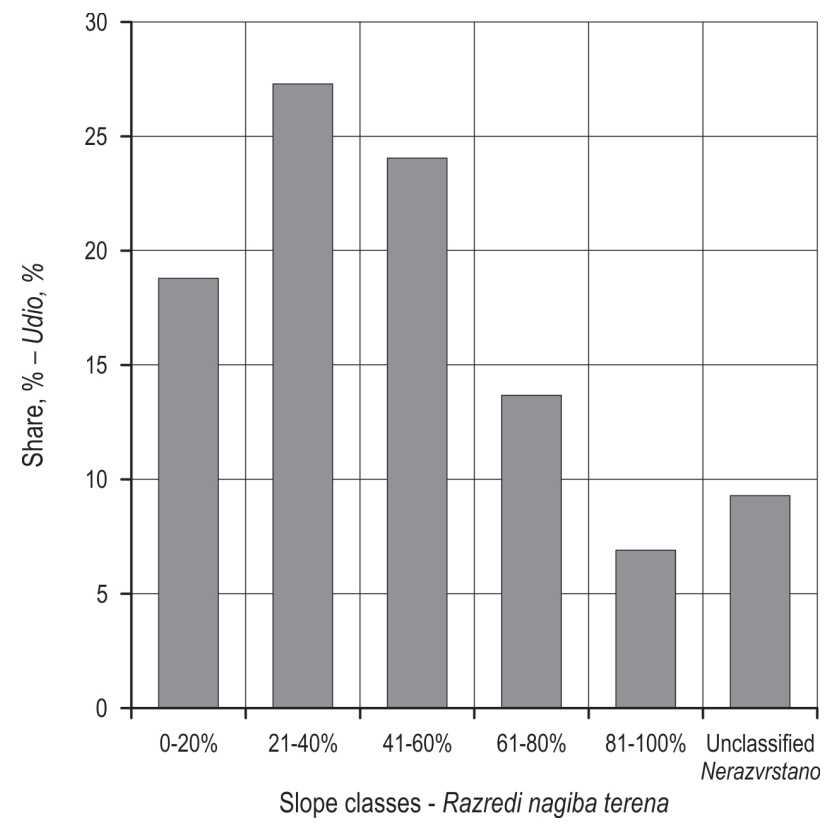

Fig. 5 Slope classes distribution

Slika 5. Udio i raspodjela razreda nagiba terena
Fig. 5 shows the distribution of slope classes according to INFC 2005. The most represented class is the second, while less than $20 \%$ of forests are in lowland districts and more than $40 \%$ of forests belong to classes with steep slopes. The high amount of unclassified slopes ( $9.3 \%$ of the share) is specifically due to procedural constraints and technical difficulties occurred during the assesment, as well as the waiver to provide detailed information for areas not classified in any of the inventory categories.

The accessibility was estimated on the basis of the distance (Table 2) and gradient (difference in altitude) (Table 3) between the sampling point and the nearest forest infrastructure (INFC, 2007), without distinction between primary and secondary roads.

Table 2 Accessibility by linear distance classes

Tablica 2. Udio pristupačnosti šuma prema razredima linearne udaljenosti

\begin{tabular}{|c|c|c|c|c|}
\hline \multicolumn{5}{|c|}{ Distance classes - Razredi linearne udaljenosti } \\
\hline $0-500 \mathrm{~m}$ & $501-1000 \mathrm{~m}$ & $1001-2000 \mathrm{~m}$ & $\begin{array}{c}\text { Over } 2000 \mathrm{~m} \\
\text { Više od } 2000 \mathrm{~m}\end{array}$ & $\begin{array}{c}\text { Unclassified } \\
\text { Nerazvrstano }\end{array}$ \\
\hline $54.7 \%$ & $9.8 \%$ & $4.8 \%$ & $1.40 \%$ & $29.30 \%$ \\
\hline
\end{tabular}

Table 3 Accessibility by gradient classes

Tablica 3. Udio pristupačnosti šuma prema razredima nagiba terena

\begin{tabular}{|c|c|c|c|}
\hline \multicolumn{4}{|c|}{ Gradient classes - Razredi nagiba terena } \\
\hline $0 \pm 100 \mathrm{~m}$ & $101 \pm 400 \mathrm{~m}$ & $\begin{array}{c}\text { Over } \pm 400 \mathrm{~m} \\
\text { Više od } \pm 400 \mathrm{~m}\end{array}$ & $\begin{array}{c}\text { Unclassified } \\
\text { Nerazvrstano }\end{array}$ \\
\hline $57.7 \%$ & $11.5 \%$ & $1.5 \%$ & $29.30 \%$ \\
\hline
\end{tabular}

More than $50 \%$ of the share is in the first class of both parameters, while the high amount of unclassified situations is mainly imputable to inaccessible areas. Other important paramenters, i.e., soil bearing index, have influence on forest accessibility and may affect harvesting and extraction machineries choice, but they were not taken into account in INFC2005.

Forest opening, through a careful planning, designing and maintenance of road network is of primary importance in forest utilization and crucial for a sustainable management (Grigolato et al. 2019). Primary forest road system, including truck forest roads, is a key element to allow wood production in addition to many other social and environmental purposes, i.e., research and monitoring activities, recreation, fire protection and extinguishing (Eastaugh et al. 2011, Stefanović et al. 2016, Laschi et al. 2016). Secondary forest communications, i.e., skid 
roads and skid trails, are determinant for basic vehicle-to-timber access during timber extraction (Đuka et al. 2017).

In a study performed by Baldini et al. (2009), based on field surveys in several regions of Italy, average values of $18 \mathrm{~m} /$ ha for primary classical openness and $17 \mathrm{~m} /$ ha for secondary classical openness have been found, considering both public and private roads. About the latter value, it is important to emphasize that secondary openness only includes skid roads, as skid trails are not registered in Italy. However, classical openness provides information about density of forest roads, but says little about qualitative aspects, such as their distribution (Pentek et al. 2011). According to the same authors of the above mentioned study, such values of road densities are scarce and not sufficient for a suitable forest management, considering the mechanization level, and may affect logging distances especially in slope classes above the second, highly represented in Fig. 5, limiting forest utilization in a $150-200 \mathrm{~m}$ buffer area around the existing roads to be cost-effective. In order to obtain a more rational accessibility, the optimal forest road density should be at the cost breaking point between skidding and road building and maintenance costs (Leonardi 1966, Leibundgut 1971).

Fig. 6 shows results about the main working systems for wood harvesting adopted by logging companies, according to a study by Picchio et al. (2010).

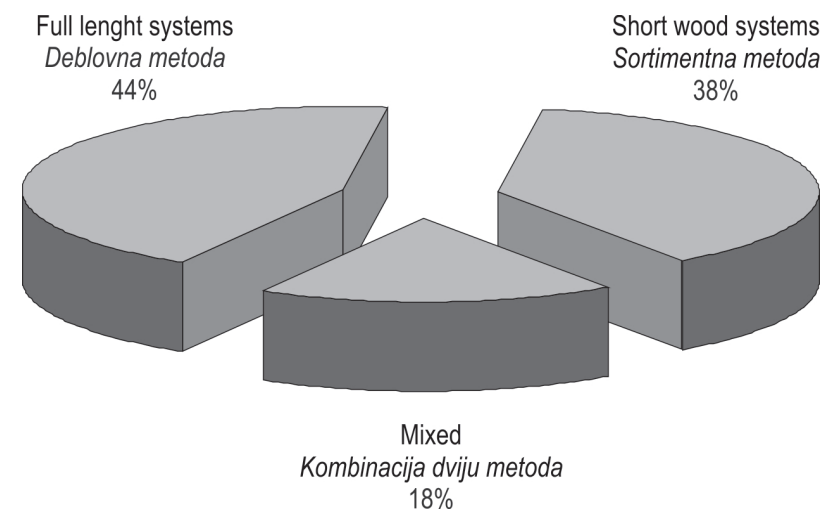

Fig. 6 Main forestry utilization systems adopted

Slika 6. Dominantne metode pridobivanja drva

Full-length system accounts for $44 \%$ of the total harvested wood, and includes tree-length method, where trees are felled, delimbed, and topped directly in the stump area and then transported to the landing, and whole-tree method, where trees are felled and transported to the landing with the branches and top still intact. The waste material resulting from wood processing in full-length system can also be exploited through biomass energy production, which is recently having a growing attention in Italy (Pantaleo et al. 2009), and shows a potential in providing environmental and socio-economic benefits (Proto et al. 2014). Short wood system accounts for $38 \%$ of the total harvested wood, consisting in felling and processing trees in the stump area into logs, later transported to the landing or roadside. Cut-to-length technology is the main short wood system adopted in the whole Southern Italy (Zimbalatti et al. 2008, Proto et al. 2014), generally operated through chainsaw and ground-based methods for wood extraction even in steep slope conditions (Zimbalatti et al. 2010). The most widespread extraction systems, mostly adopted by small-scale operators, are winching-skidding (Picchio et al. 2012), tractors with forwarding bins and pack mules and chutes, today made on PVC, which are getting increasingly popular among public forest operators (Picchio et al. 2009). In the Alpine area and other mountainous regions, wood extraction on steep slopes and rough terrain is also performed by cable logging systems, accounting for about $10 \%$ to $20 \%$ of the total harvested wood in Italy (Grulois 2007); in this regard, the most modern yarder developments originate in North Italian landscape (Lombardini et al. 2015). Cableways can also enhance forest logging in sites not suited to tractor traffic (because of terrain factors or lack of accessibility, as already pointed out) as well as in wet and sensitive sites, where soil preservation is primary (Erber et al. 2020). Harvesters have been introduced in Italy at the beginning of 2000 (Spinelli et al. 2011) with a subsequent growth of the Italian fleet, which counted over 200 units by 2013, including harvesters, processors and forwarders (Spinelli et al. 2013). However, the use of highly mechanized harvesting results limited in many areas because of orographic, technical and economic restraints (Picchio et al. 2010).

\section{Final remarks - Zaključna razmatranja}

According to the last projection of INFC2015 preliminary results, forest cover in Italy has been growing significantly in the last decade, enhancing forest resources in both qualitative and quantitative terms. In this scenario, given the limited internal supply of woody products and along with the growing demand for energy and quality timber, new perspectives can be achieved by forest sector. However, the growing environmental awareness, decreasing 
the tolerance for soil disturbance (Abbas et al. 2018), in addition to the recent delicate socio-economical situation, make it unavoidable to provide such forest resources in a sustainable manner, through an accurate management which is able to guarantee economical, environmental and social benefits. For example, planning of forest road network is one of the most powerful instruments to connect those three pillars, by improving forest accessibility in order to allow forest enterprises to work in a safe and low impact way, as well as boosting their incomes and the stumpage value. New possibilities offered by technologically advanced machines and working methods, which can often be competitive with traditional methods in well-opened forests, should be considered along with their demand for forest accessibility and professional training of operators. In this perspective, an optimally planned and distributed network of primary and secondary communication infrastructures is therefore a founding principle to achieve a rational, high-quality and efficient management of forest ecosystems (Pičman et al. 2011).

Italian forest management is meant to - indeed it has to - make a qualitative leap if it is to be able to get the better of the challenges that lie ahead.

\section{Acknowledgments - Zahvala}

A special thank to the University of Zagreb, Department of Forest Engineering, and particularly to Assist. Prof. Ivica Papa for the kind availability and willingness in supporting and providing indications during the whole editing process.

\section{References - Literatura}

Abbas D., Di Fulvio F., Spinelli R., 2018: European and United States perspectives on forest operations in environmentally sensitive areas. Scandinavian Journal of Forest Research 33(2): 188-201. https://doi.org/10.1080/02827 581.2017 .1338355

Agnoletti, M., 2018: Storia del bosco: il paesaggio forestale italiano. Gius. Laterza \& Figli Spa. 78-80; 94-96; 101-103; 283-288 p.

Baldini, S., Cavalli, R., Piegai, F., Spinelli, R., Di Fulvio, F., Fabiano, F., Grigolato, S., Laudati, G., Magagnotti, N., Nati, C., Picchio, R., 2009: Prospettive di evoluzione nel settore delle utilizzazioni forestali e dell'approvvigionamento del legname. In Proceedings, Terzo Congresso nazionale di Selvicoltura. Accademia Italiana di Scienze Forestali, Ministero delle Politiche Agricole, Alimentari e Forestali, Corpo Forestale dello Stato, Ministero dell'Ambiente, della Tutela del Territorio e del Mare, Regione Siciliana, Firenze, 717-728.
Baldini, S., Picchio, R., Laudati, G., 2006: Indagini sulle utilizzazioni forestali degli ultimi 50 anni nell'Italia Centro-Meridionale. Silvae 4: 189-212.

Cesaro, L., Romano, R., 2009: Politiche forestali e sviluppo rurale: situazioni, prospettive, buone prassi, 35-36.

Ciancio, O., Iovino, F., Menguzzato, G., 2002: Prove sperimentali di avviamento a fustaia con il metodo del rilascio intensivo di allievi: i cedui di leccio in Aspromonte (Calabria). Il bosco ceduo in Italia", Ciancio, O., Nocentini, S., eds., Accademia Italiana di Scienze Forestali, Firenze, 325-342.

Đuka, A., Grigolato, S., Papa, I., Pentek, T., Poršinsky, T., 2017: Assessment of timber extraction distance and skid road network in steep karst terrain. iForest 10(6): 886-894. https://doi.org/10.3832/ifor2471-010

Eastaugh, C. S., D. Molina, 2011: Forest road networks: metrics for coverage, efficiency and convenience. Australian Forestry 74(1): 54-61. https://doi.org/10.1080/0004915 8.2011.10676346

Erber, G., Spinelli, R., 2020: Timber extraction by cable yarding on flat and wet terrain: a survey of cable yarder manufacturer's experience. Silva Fennica 54(2): article id 10211. https://doi.org/10.14214/sf.10211

Ermacora, M., 2009: Lo sfruttamento delle risorse forestali in Italia durante il primo conflitto mondiale. Venetica 23(20): 53-75.

Gabbrielli, A., 2007: Le vicende storiche e demografiche italiane come causa dei cambiamenti del paesaggio forestale. Annali, 133-166.

Gasparini, P., Di Cosmo, L., 2016: Italy. In: Vidal C., Alberdi I., Hernández Mateo, L., Redmond, J. (eds) National Forest Inventories. Springer, Cham, 485-506.

Gasparini, P., Marchetti, M., 2019: Patrimonio Forestale. In: Rapporto sullo stato delle foreste e del settore forestale in Italia. Direzione Generale Foreste, Rete Rurale Nazionale, Ministero delle politiche agricole, agroalimentari, forestali e del turismo. Compagnia delle Foreste, Arezzo, 72-98.

Grigolato, S., Marchi, E., Laschi, A., Cavalli, R., 2019: Riflessioni sulla viabilità forestale e opere connesse a supporto delle iniziative per la predisposizione dei decreti attuativi del Testo Unico in materia di Foreste e Filiere Forestali. Forest@-Journal of Silviculture and Forest Ecology 16(1): 49-55. https://doi.org/10.3832/efor3175-016

Grulois, S., 2007: Cable yarding in France: past, present and perspectives. Proceedings of the International Mountain Logging and $13^{\text {th }}$ Pacific Northwest Skyline Symposium, $5 \mathrm{p}$.

Hirsch, F., Korotkov, A., Wilnhammer, M., 2007: Private forest ownership in Europe. Forest 13: 5. https://doi. org/10.3929/ETHZ-A-006311424

INFC, 2007: Le stime di superficie 2005 - Prima parte. Autori G., Tabacchi, F., De Natale, L., Di Cosmo, A., Floris, 
C., Gagliano, P., Gasparini, L., Genchi, G., Scrinzi, V., Tosi. Inventario Nazionale delle Foreste e dei Serbatoi Forestali di Carbonio. MiPAF - Corpo Forestale dello Stato - Ispettorato Generale, CRA.

Laschi, A., Neri, F., Brachetti Montorselli, N., Marchi, E., 2016: A Methodological Approach Exploiting Modern Techniques for Forest Road Network Planning. Croatian Journal of Forest Engineering 37(2): 319-331.

Leibundgut, H., 1971: Integrale Walderschlissung. Forstwissenschaftliches Centralblatt.

Leonardi, S., 1966: Aspetti economici delle operazioni di esbosco con riguardo alla rete di strade in Alto Adige. In Atti del 6 Congresso Forestale Mondiale di Madrid.

Lombardini, C., De Francesco, F., Aminti, G., 2015: An analysis of whole tree harvesting in North Italian cable logging operations. In Forest engineering: making a positive contribution. Abstracts and Proceedings of the $48^{\text {th }}$ Symposium on Forest Mechanization, Linz, Austria. Institute of Forest Engineering, University of Natural Resources and Life Sciences, 321-323 p.

Mariano, A., Seri, G., 2019: Prodotti Legnosi. In: Rapporto sullo stato delle foreste e del settore forestale in Italia. Direzione Generale Foreste, Rete Rurale Nazionale, Ministero delle politiche agricole, agroalimentari, forestali e del turismo. Compagnia delle Foreste, Arezzo, 174-177.

Pantaleo, A., Pellerano, A., Carone, M. T., 2009: Potentials and feasibility assessment of small scale CHP plants fired by energy crops in Puglia region (Italy). Biosystems Engineering 102(3): 345-359. https://doi.org/10.1016/j.biosystemseng.2008.12.002

Pentek, T., Pičman, D., Nevečerel, H., Lepoglavec, K., Papa, I., Potočnik, I., 2011: Primary forest opening of different relief areas in the Republic of Croatia. Croatian Journal of Forest Engineering 32(1): 401-416.

Picchio, R., Blasi, S., Sirna, A., 2010: Survey on Mechanization and Safety Evolution in Forest Works in Italy. In International Conference Ragusa SHWA2010, 16-18 p.

Picchio, R., Maesano, M., Savelli, S., Marchi, E., 2009: Productivity and energy balance in conversion of a Quercus cerris L. coppice stand into high forest in Central Italy. Croatian Journal of Forest Engineering 30(1): 15-26.

Picchio, R., Magagnotti, N., Sirna, A., Spinelli, R., 2012: Improved winching technique to reduce logging damage. Ecological Engineering 47: 83-86. https://doi. org/10.1016/j.ecoleng.2012.06.037

Pičman, D., Pentek, T., Nevečerel, H., Papa, I., Lepoglavec, K., 2011: Possibilities of application of relative openness in secondary forest opening of slope forests in Croatia. Croatian Journal of Forest Engineering 32(1): 427-430.

Proto, A. R., Zimbalatti, G., Abenavoli, L., Bernardi, B., Benalia, S., 2014: Biomass production in agroforestry systems: VE Ri. For Project. In Advanced Engineering Forum 11: 58-63. Trans Tech Publications Ltd. https://doi. org/10.4028/www.scientific.net/AEF.11.58

Spinelli, R., Magagnotti, N., 2011: The effects of introducing modern technology on the financial, labour and energy performance of forest operations in the Italian Alps. For. Policy Econ. 13(7): 520-524. https://doi.org/10.1016/j. forpol.2011.06.009

Spinelli, R., Magagnotti, N., Facchinetti, D., 2013: Logging companies in the European mountain: An example from the Italian Alps. Int. J. For. Eng. 24(2): 109-120. https://doi. org $/ 10.1080 / 14942119.2013 .838376$

Stefanović, B., Stojnić, D., Danilović, M., 2016: Multi-criteria forest road network planning in fire-prone environment: a case study in Serbia. Journal of Environmental Planning and Management 59(5): 911-926. https://doi.org /10.1080/09640568.2015.1045971

Venanzi, R., Picchio, R., Piovesan, G., 2016: Silvicultural and logging impact on soil characteristics in Chestnut (Castanea sativa Mill.) Mediterranean coppice. Ecological Engineering 92: 82-89. https://doi.org/10.1016/j.ecoleng.2016.03.034

Zimbalatti, G., Proto, A. R., 2008: Cable logging opportunities for firewood in Calabrian forest. Biosyst Eng. 102(1): 63-68. https://doi.org/10.1016/j.biosystemseng.2008.10.008

Zimbalatti, G., Proto, A. R., 2010: Productivity of forwarders in south Italy. Formec Italy. 


\section{Sažetak}

\section{Zastupljenost šuma i način gospodarenja šumama u Italiji}

Tijekom stoljećâ, zbog višestrukih promjena u socioekonomskim uvjetima, potrebama i tehničkim mogućnostima, talijanske šume i način gospodarenja šumskim ekosustavima prošli su kroz dinamičan i složen proces evolucije. U posljednjem desetljeću površina šuma $i$ šumskoga zemljišta u Italiji neprestano raste $i$ danas pokriva gotovo 11 milijuna hektara, što čini 36,4\% ukupnoga nacionalnoga teritorija. Analizama nacionalne inventure šuma (INFC2005) obuhvaćeno je $i$ opisano nekoliko kvantitativnih i kvalitativnih aspekata šumskih ekosustava, kao što su: sastav vrsta, podaci o stvarnim i dostupnim dronim zalihama, strukturi vlasništva, stupnju iskoristivosti etata, stupnju otvorenosti šuma, značajkama i kategorijama terena te mnogih drugih. Najzastupljeniji je tip šumske sastojine u Italiji »panjača s pričuvcima«, dok su mnoge šumske sastojine u zreloj fazi koje čekaju konverziju u prijelazni oblik sastojina. Što se tiče dominantnih načina sječe i metoda pridobivanja drva, prevladava deblovna metoda pridobivanja drva te privlačenje/privitlavanje drva po tlu uz napomenu kako je na mnogim područjima nedovoljna otvorenost šuma u kombinaciji s velikom srednjom udaljenosti privlačenja, pogotovo na terenima gdje prevladavaju veliki nagibi terena, ograničavajući čimbenik za sječu i izradbu drva na održiv i troškovno prihvatljiv način. Moderna rješenja omogućena tehnološkim napretkom, uz rastuću ekološku svijest i potrebu za održivim upravljanjem na višestrukim razinama, zahtijevaju kvalitativni iskorak kako bi se poboljšalo učinkovito upravljanje šumskim ekosustavima, u ovim izazovnim vremenima u kojima se Italija nalazi, uz prijeko potrebno profesionalno udruživanje izvođača radova.

Ključne riječi: šumski resursi Italije, nacionalna inventura šuma, gospodarenje šumama, pristupačnost šumskoj površini, održivo gospodarenje

Received (Primlieno): August 23, 2020.

Accepted (Prihvaćeno): November 04, 2020.
Author's address - Adresa autora:

Nicolò Di Marzio

e-mail: n.dimarzio@libero.it

University of Tuscia

Faculty of forestry

Department of Agricultural and Forest Sciences

Via San Camillo de Lellis, snc

01100 Viterbo

ITALY 
